Guy's Hospital Medical School under the guidance of Prof. G. E. H. Foxon.

Of the more indefinite objectives, that of getting to know and working in conjunetion with Brazilian scientists has most certainly been achieved. All the members of the party are grateful for the splendid assistance and co-operation received at every turn, not only from those who have been named here, but also from all those whom they met both professionally and socially who helped to make their visit so pleasant; in particular, mention should be made of the British vice-consuls at Manaus and Belém.
In conclusion, the members of the party and all concerned with the expedition thank the many individuals, commercial companies, and public bodies who by their financial support and other aid enabled this journey to be undertaken. Among the public bodies the following should be especially mentioned: the Zoological Society of London, the Medical Research Council and particularly the Wellcome Trust, which by a generous guarantee made the project possible.

I. R. BISHOP

G. E. H. Foxox

\title{
NUTRITION AND ITS INTERNATIONAL RECOGNITION
}

\section{By SIR RUDOLPH A. PETERS, F.R.S.}

T HIS subject has a very long history, but in spite of this the International Union of Nutritional Sciences is not yet accepted as one of the 'international unions' of the International Council of Scientific Unions--even at a time when we all know that a proper knowledge of nutrition is more than ever necessary to save the increasing population of the world from famine. A haphazard use of food does not matter so much when there is plenty, because the body can adapt itself to a badly balanced diet to some extent. It is, however, now vital to know how to use our food with the greatest economy. Many years ago, for example, Chittenden and his colleagues (Chittenden, R. H., Physiological Economy in Nutrition, New York, 1904) showed that protein requirements of adults could be much reduced without damage to health.

Why, then, is there delay in accepting nutritional science as a separate science? Probably part of the reason is the complexity of the subject. It involves physics, chemistry, physiology, biochemistry, pharmacology, pathology and medicine, and extends to sociology especially in regard to food habits and the preparation of foodstuffs. Each of these sciences sees only a small part of a complexity. Fifty years ago, nutrition seemed almost synonymous with biochemistry and Gowland Hopkins shared a Nobel Prize with Eijkmann for his part in delineating vitamins, and for showing so clearly that nutrition was a qualitative subject and not just a matter of energetics, the so-called isocaloric value of foodstuffs. This was followed by an outburst of activity in isolating and synthesizing various vitamin factors, in the furtherance of which the U.K. Medical Research Council played a considerable part. For the past eighteen years, however, those concerned with granting finance for research have turned to 'pastures new', witness: The isolation of enzymes, the unravelling of protein structure and the excitement of the nucleic acids and geneties. The result is that at the present time fow research workors have been trained in the rigorous and lengthy discipline of nutritional research - which is emphatically not just 'the feeding of a few rats'. From many points of view, even from that of space travel, we want to know much more about the interaction of the various compounds making up a diet.

The problems extend, of course, beyond man into the animal kingdom. In agriculture, for example, there is the problem of digestion in the ruminant. The micro-organisms in the rumen, bacteria and protozoa, by a controlled fermentation set up a digestion of substances such as cellulose, which the secreted enzymes of the digestive tract cannot digest; and so they turn inedible substances into food for man. Anatomy, physiology, biochemistry and microbiology are all involved in this work; but none of these sciences, as such, is interested in the implications of ruminant digestion for the utilization of the world's grassland to feed its populations.

Again, it is the business of the soil scientist, who may be geographer, physicist and chemist, to show that certain strata of the world's surface lack particular elements, such as coppor or cobalt; and the biochemist will relato this to plant growth and to enzymes present. It is the business of the nutritionist to relate these discoveries to the health of the grazing animal, and so ultimately to the food supply of populations. Actually, it has often been investigated in reverse, starting with the ill-health of the animal on the natural vegetation.

It is to be noted that the International Union of Nutritional Sciences has been in existence since 1948; and it has at present the support of seventeen national members of the International Council of Scientific Unions. At intervals of three years, it has held six successful international congresses; the last one was in Fdinburgh under the presidency of Sir David Cuthbertson. There will always be a need for close relations with organizations such as the Food and Agriculture Organization, the World Health Organization and Unesco; but this very necessity makes it all the more important for nutrition to have a firm scientific basis within the organization of the International Council of Scientific Unions.

\section{NEWS and VIEWS}

\section{Science Research Council Support for University Science and Technology \\ The Science Rosearch Council has set up a new} University Science and Technology Board under the chairmanship of Sir Ewart Jones, Waynflete professor of organic chemistry in the University of Oxford, to advise on the support which the Council should give to scienco and technology in the univorsities. The new Board will advise the Council on the award of grants for the support of university research, as well as studentships and fellow- ships for the training of young postgraduate scientists: support for university scientific research and advanced training will thus be closely integrated. The scope of the Board will include science and technology; it will therefore work in close touch with the other Research Councils and the Ministry of Technology. The Council has already set up a Nuclear Physics Board under the chairmanship of Prof. C. F. Powell, and an Astronomy, Space and Radio Board under the chairmanship of Sir Bernard Lovell. Part of the support previously given to university research and training by the Department of Scientific and Industrial 